Authors' contribution:

A. Study design/planning

B. Data collection/entry

C. Data analysis/statistics

D. Data interpretation

E. Preparation of manuscript

F. Literature analysis/search

G. Funds collection
DOI: $10.5604 / 17310652.1129240$

\section{DETERMINANTS OF PHYSICAL ACTIVITY IN ADULT POPULATION VS. EXISTING RECOMMENDATIONS}

\author{
Dorota Lizak ${ }^{1,2}$ ABCDEFG, Wojciech Czarny ${ }^{3 \text { ACF }}$
}

\author{
Health and Medical Sciences Faculty, Psychology and Humanities Sciences Faculty at An- \\ drzej Frycz Modrzewski Krakow University, Poland \\ Józef Dietl Specialized Hospital, Internal Diseases and Alergology Unit, Krakow, Poland \\ 3 Physical Education Faculty, University of Rzeszów, Poland
}

Key words: determinants of physical activity, physical effort, movement, physical activity, physical activity recommendations, hypokinesis

\title{
Abstract
}

Purpose: The aim of the study is to assess the determinants, level and type of physical activity undertaken by adults in relation to the recommendations on physical activity.

Basic procedures: The study group consisted of 225 people aged 18-68 years. Selection of the sample was stratified. As the research technique the Polish version of the International Physical Activity Questionnaire (IPAQ) was used, short version. For statistical analysis, Statistica $10 \mathrm{PL}$ was used. In all analyses considered relevant were those effects, for which the level of test probability $p$ was lower than the assumed relevance level $a=0.05(p<0.05)$.

Main findings: The study shows that women practice less intensively and for shorter time than men. As in the case of gender and physical activity, there is a significant difference $(p=0.0170)$ as far as the type of education, and frequency of undertaking intense and moderate physical activity are concerned. People with a secondary education undertake both intense and moderate physical activity more often and for longer periods of time, in comparison to people with higher and primary education. The research shows that physical activity levels do not increase with the education level. There is not a statistically significant difference between profession and the degree of intensity of exercise.

Conclusions: There is a significant correlation between gender and education, and performed physical activity. Age and profession are not factors determining the level of physical activity.

\section{Introduction}

Technicization of life has brought mankind much good, but eventually resulted in significant reduction of humans' basic physical activity, sometimes even to a minimum. Recommendations on physical activity developed by scientists are used to maintain and build up health, to "optimize well-being" and to improve health if methodically observed. Because "norm" is regularity, and thanks to the standards and recommendations developed, assessments and comparisons in relation to norms are possible to be made.
Comprehensive development of young people - from birth to maturity - takes place in subsequent, closely connected stages. In this development, family plays a very important role, being the biological, social, cultural, economic and educational environment [1]. Physical activity carried out within the framework of physical culture is of key importance for developing the pattern of activity perpetuated during young age and promoted during adulthood. Not without significance is also following the positive example of people in the immediate environment, because who else but a parent, a teacher or a friend can be most motivating? 
By increased physical activity we mean any form of exercise that causes in human body an increase in energy expenditure above the resting value. Depending on the nature of the exercise, its intensity or duration, there are changes in both the functional capacity of individual systems, as well as quantitative (morphological) and qualitative changes on the level of tissues and individual cells [2].

Regular physical activity should be one of the basic elements of human life. It bolsters up good health (health promotion) and prevents development of many chronic diseases, such as cardiovascular and metabolic diseases, and diseases of the musculoskeletal system (primary prevention). In a patient group it not only helps in the treatment of diseases but also prevents complications (secondary prevention) [3].

One of the basic elements of health policy in many countries is promoting healthy eating habits and physical activity. Overweight, obesity, cardiovascular diseases disease entities that bear the name "diseases of civilization" are also a social problem. Apart from the genetic factors that may cause them, they may also often result from hypokinesia. Technicization of life has brought mankind much good, however, it resulted over time in a significant decrease in humans' basic physical activity, a decrease that sometimes reaches the minimum. In the current National Health Programme (Narodowy Program
Zdrowia, NPZ), in force in Poland for years 1996-2005 and 2007-2015, one of the first operational objectives is: "Increasing the level of physical activity of the population;" in the revised version, currently in force, reducing the incidence of obesity also has its place among the goals $[4,5]$.

Regardless of the capabilities and limitations, as well as one's own beliefs, it is important to keep in mind the principle which Jegier states [6]: "Regular physical activity is human's obligation towards their own health".

In recent years, the heXalth benefits coming from recreational physical activity are better understood and appreciated, science attaches equal value to recreation in both improving the state of human health and prolonging overall fitness [7]. Physical effort, depending on intensity, is usually divided into three groups [4]:

- low-intensity effort (light) - warmth felt, slightly more rapid breathing and heart rate (e.g. a walk, light work in the garden);

- moderate-intensity effort - warmth clearly felt, rapid breathing (e.g. a brisk walk, climbing stairs, cycling, swimming, dancing);

- high-intensity effort - sweating, shortness of breath (feeling of being out of breath), clearly felt rapid heart rate (e.g. aerobics, jogging, fast swimming, fast dancing).

Table 1. Physical activity recommendations in prevention of cardiovascular diseases according to European guidelines of 2012

- healthy adults of all ages should spend 2.5-5 hours a week on physical activity or aerobic exercise of at least moderate intensity, or 1-2.5 hours a week on exercise of high intensity

- people leading a sedentary lifestyle are advised to start physical activity from low-intensity exercises

- physical activity / aerobic training can be undertaken in a number of training units, but each should last for $\geq 10$ minutes and be evenly distributed throughout the week, i.e. on 4-5 days a week

Source: Jegier (2013) on the basis Perk et al. (2012)

Table 2. Physical activity recommendations for adults, clinically healthy persons aged $18-65$, in order to maintain good health or to improve it (by ACSM and AHA, 2007)

Aerobic physical activity (improving endurance)

- moderate-intensity (3-6 METs), performed for at least 30 minutes 5 times a week (exercise of shorter duration can accumulate up to 30 minutes each day, but the training unit has to take at least 10minutes), or

- high intensity (above $6 \mathrm{METs}$ ), performed for at least 20 minutes, three times a week, or

- a combination of physical exercise of moderate and high intensity of 450-750 MET * min $^{*}$ week $^{-1}$

Resistance exercise involving large muscle groups

- triggering large muscle groups, improving muscle strength and endurance - at least 2 times a week;

- 8-10 exercises using the large muscle groups - 2 times a week or more in non-consecutive days;

- resistance used should enable a person to perform 8-12 repetitions without longer fatigue

Source: Jegier (2013) on the basis of recommendations from ACSM and AHA 2007 (Haskell et al., 2007)

MET - Metabolic Equivalent 
The recommendations of physical activity were presented, among others, by Jegier [3], who developed tables based on the data gathered by researchers from Europe and the USA.

The aim of the study is to assess the determinants, level and type of physical activity undertaken by adults in relation to the recommendations on physical activity.

\section{Material and methods}

The study was conducted in Tarnów, lasting from September to November 2013. Participation in the study was voluntary, and the sampling method used was the layered method, with the layers being demographic variables: age, gender, education and occupation. The study group consisted of parents and grandparents of primary school students, as well as people from the school community. The research technique used was the Polish version of the International Physical Activity Questionnaire (IPAQ), short version. For qualitative variables, number and percentage was calculated for each level of a variable analyzed. Because the variables in question do not have normal distribution, a nonparametric MannWhitney test was used to compare the two groups. For purposes of comparing more than two groups (level of education, professional groups), the nonparametric ANOVA test by Kruskal-Wallis was used. The results are shown in Tables and illustrated by means of categorized histograms. In all analyses, considered relevant were those effects, for which the level of test probability $p$ was lower than the assumed relevance level $a=0.05$ $(p<0.05)$.

\section{Results}

The study group consisted of 225 persons, of which $55.1 \%$ were women and $44.4 \%$ men, and $0.4 \%$ did not reveal their gender. The population spanned across 1868 years, the average age of the respondents was 40.5 years. The most numerous group of subject where those aged 30-40 years. (Fig. 1).

More than half of the respondents had secondary education $(55.1 \%)$ and a significant proportion of the subjects had higher education (40\%). Relatively few respondents had professional and basic education. Some respondents did not disclose their education level (Fig. 2).

When comparing physical activity in relation to the gender of respondents, it can be observed that a statistically significant difference exists only between the activity of intensive and moderate levels $(p=0.0001$ and $p=0.0035$, respectively). It can be concluded that women rarely undertake intense physical activity during the week in comparison to men (Fig. 3 and 4, Tab. 3).

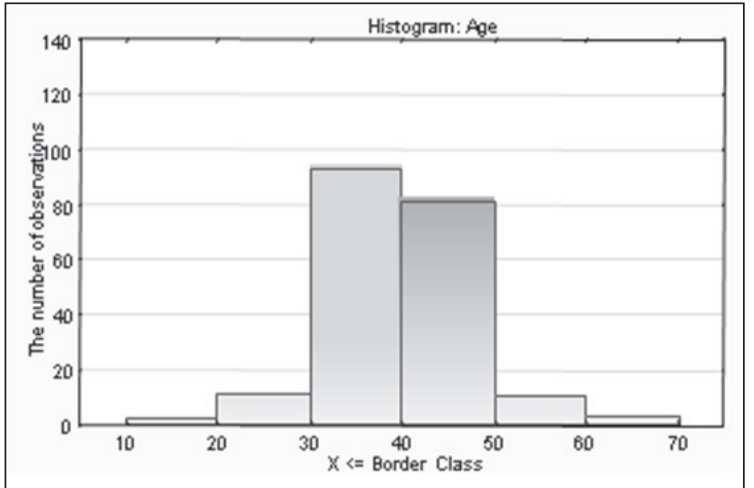

Fig. 1. Characteristics of the study group based on the age

For both men and women, the mean duration of intensive activity in the study group was 149.77 minutes/week, with the median 120.00 minutes/week. The analysis of the data shows that the subjects spend approximately 2.5 hours a week for this kind of activity and perform it within 2.5 days (median 2.00 days/week). This means that for intensive physical activity, the subjects spend only two hours a day, two days a week, so it can be assumed that its average duration is 60 minutes per day. Most women undertake intensive physical effort less frequently and for shorter periods of time $(0-100$ minutes/week on average), while men do it more often and for longer periods of time (100-200 minutes/week) (Fig. 3 and 4). It is similar in the case of moderately intensive activity (Fig. 5 and 6, Tab. 3).

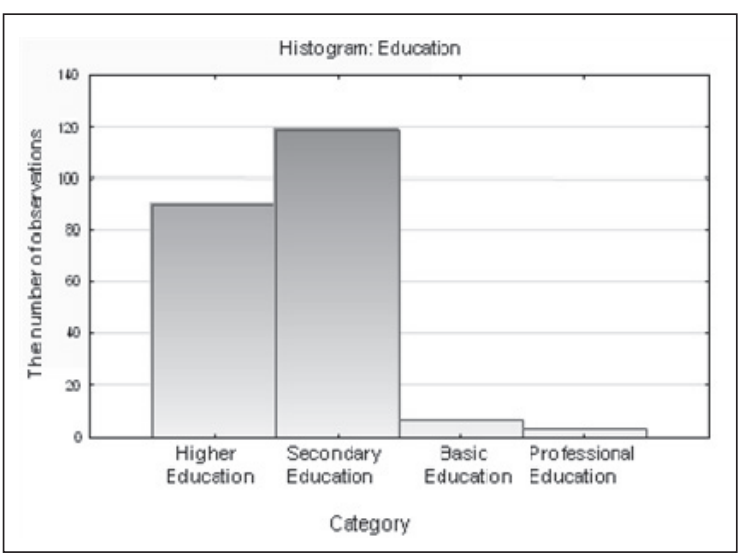

Fig. 2. Characteristics of the study group based on the education level

Age was also taken into consideration as a determinant of physical activity. Most of the subjects were $30-40$ years old, which could indicate a higher level of physical activity in relation to other people. As it turns out, in this case, age is not a factor determining the level of physical 


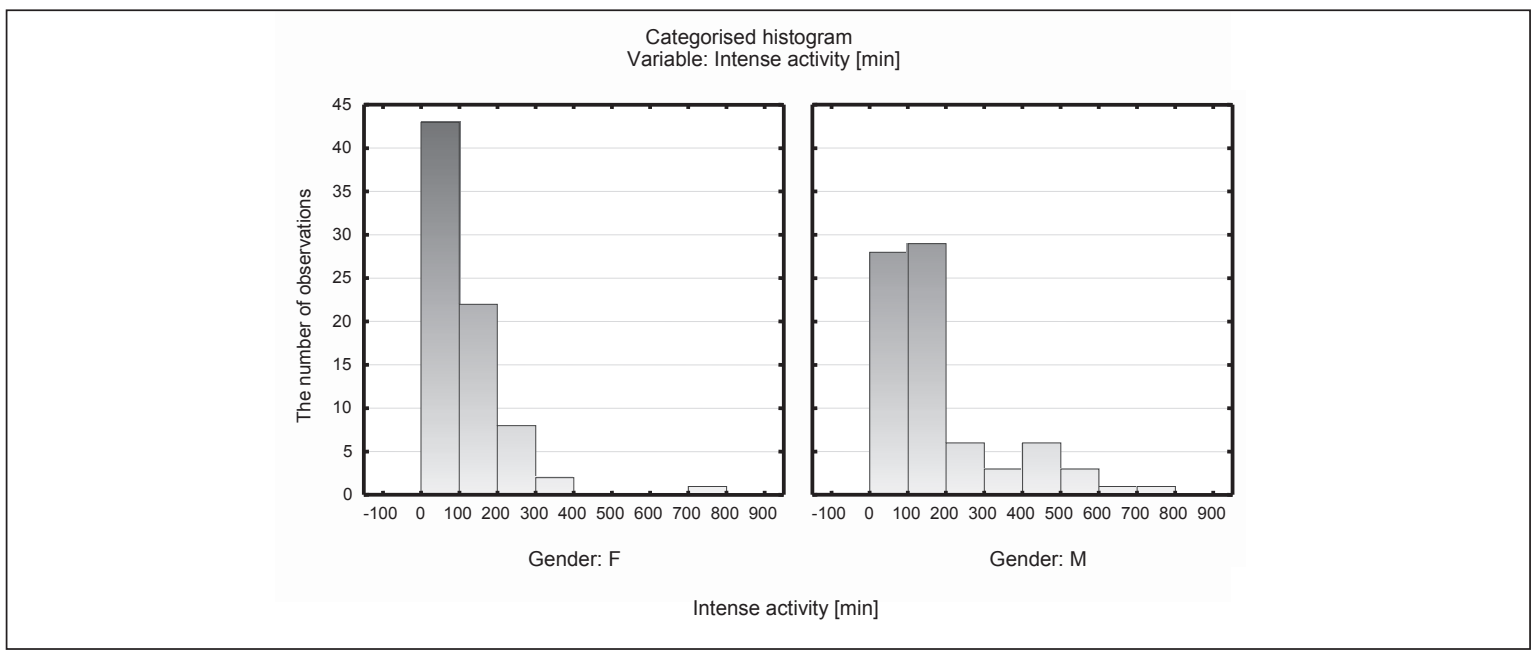

Fig. 3. Intensive physical activity in minutes per week and gender

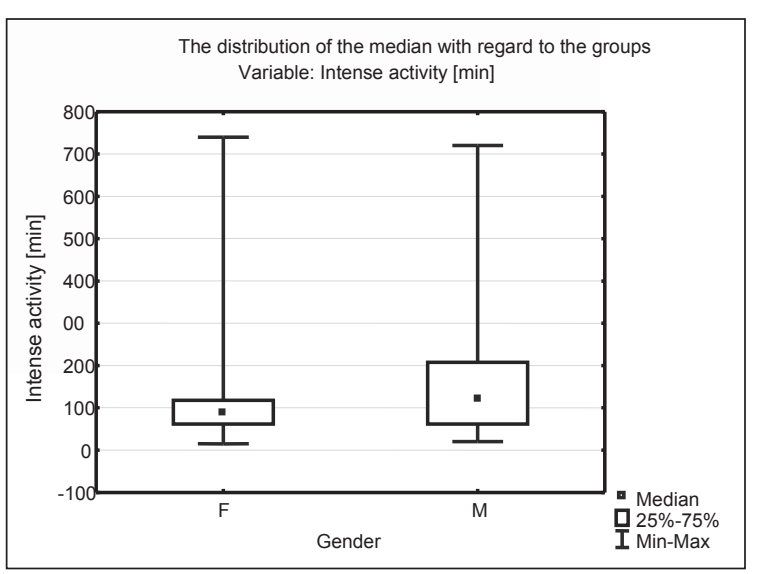

Fig. 4. The distribution of median based on gender in intensive physical activity in minutes per week activity of the subjects $(p>0.05)$ (Tab. 4). Since both walking and sitting are not statistically significant in the study group in relation to age, and coincide with the lines depicting the intensive and moderate activity in relation to age, they have not been shown in Figure 7 (Fig. 7).

The next determinant taken into consideration, capable of creating differentiated levels of physical activity was education. The research shows that the level of physical activity does not increase with the level of education. It can be argued that people with secondary education (52.8\%), perform a broader range of activities because of their professions, of which exercise is an integral part, whereas people with higher education $(40 \%)$, due to the nature of their work (often intellectual) are less physically active. This stands in opposition to

Table 3. Comparison of physical activity by gender - results summary

\begin{tabular}{|c|c|c|c|c|c|c|c|}
\hline \multirow[t]{2}{*}{ Pair of variables } & \multicolumn{7}{|c|}{$\begin{array}{c}\text { Mann-Whitney } \mathrm{U} \text { test with variable: gender } \\
\text { Marked results are significant with } \mathrm{p} \text { value }<0.05\end{array}$} \\
\hline & $\mathrm{u}$ & z & $\mathrm{p}$ value & $Z$ corrected & $p$ value & Number F & Number M \\
\hline $\begin{array}{l}\text { Gender and intense activity (days/ } \\
\text { week) }\end{array}$ & 4364.50 & -3.80 & 0.00 & -3.86 & 0.00 & 124 & 100 \\
\hline $\begin{array}{l}\text { Gender and intense activity (min/ } \\
\text { week) }\end{array}$ & 2144.00 & -2.85 & 0.00 & -2.88 & 0.00 & 76 & 77 \\
\hline $\begin{array}{l}\text { Gender and moderate activity } \\
\text { (days/week) }\end{array}$ & 4810.50 & -2.88 & 0.00 & -2.91 & 0.00 & 124 & 100 \\
\hline $\begin{array}{l}\text { Gender and moderate activity ( } \mathrm{min} / \\
\text { week) }\end{array}$ & 2532.50 & -2.27 & 0.02 & -2.29 & 0.02 & 82 & 77 \\
\hline Gender and walking (days/week) & 5873.00 & -0.67 & 0.49 & -0.72 & 0.46 & 124 & 100 \\
\hline Gender and walking (min/week) & 5237.50 & -0.08 & 0.93 & -0.08 & 0.93 & 111 & 95 \\
\hline Gender and walking (hours/week) & 5949.50 & 0.51 & 0.60 & 0.52 & 0.60 & 124 & 100 \\
\hline Gender and sitting (min/week) & 5960.00 & 0.49 & 0.61 & 0.49 & 0.61 & 124 & 100 \\
\hline
\end{tabular}

Significant differences $(p<0.05)$ in relation to gender are only for intense and moderate activity. The corresponding $p$-values are indicated in the table in black bold. 


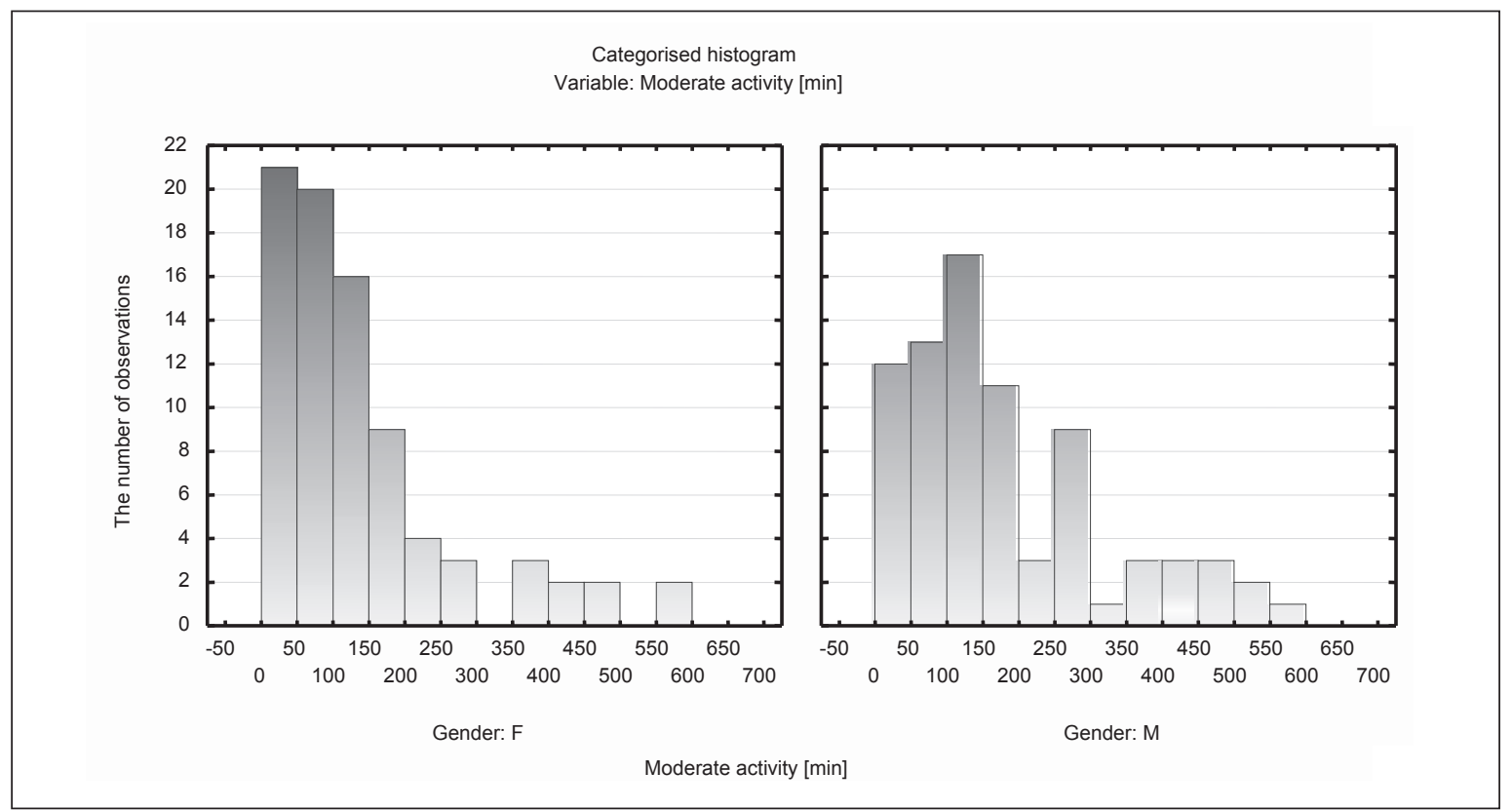

Fig. 5. Moderate physical activity in minutes per week and gender

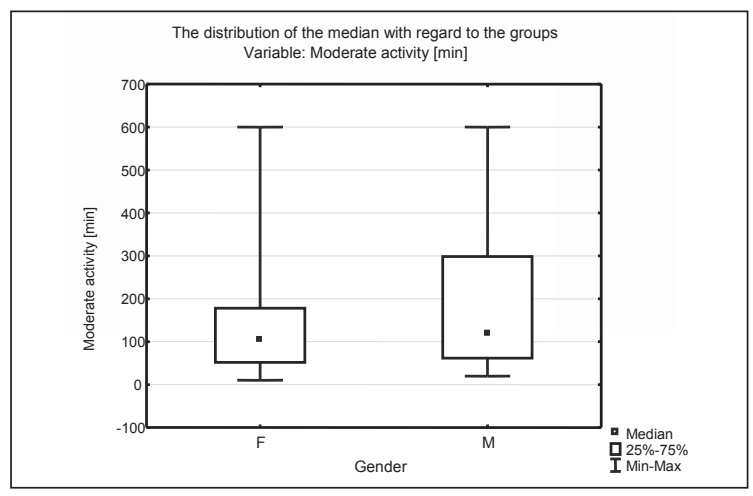

Fig. 6. The distribution of median based on gender in moderate physical activity in minutes per week the findings of some researchers, in which an increase in physical activity with increasing level of education finds confirmation (Fig. 8 and 9).

As in the case of gender and performed activity, there is a statistically significant difference $(p=0.0170)$ in relation to the type of education and the frequency of choosing intensive and moderate activity. People with secondary education undertake physical activity, both intensive and moderate, more often and for longer periods of time, compared to people with higher and primary education. People with vocational education are not included in the histogram due to their negligible (not statistically significant) number.

Table 4. Age and individual type of activity

\begin{tabular}{|c|c|c|c|c|}
\hline \multirow[b]{2}{*}{ Pair of variables } & \multicolumn{4}{|c|}{$\begin{array}{c}\text { Spearman's rank correlation } \\
\text { Marked correlations are significant with } \\
\text { p value }<0.05\end{array}$} \\
\hline & Number & $\begin{array}{l}\text { Coefficient of Spe- } \\
\text { arman's rank } \\
\text { correlation }\end{array}$ & $\begin{array}{c}\text { t (N-2) } \\
\text { test value: } \\
\text { (based on Stu- } \\
\text { dent's } \\
\text { t-test distribution) }\end{array}$ & p value \\
\hline Age and intense activity (min/week) & 137 & 0.04 & 0.56 & 0.57 \\
\hline Age and moderate activity (days/week) & 200 & 0.06 & 0.90 & 0.36 \\
\hline Age and moderate activity (min/week) & 145 & 0.07 & 0.85 & 0.39 \\
\hline Age and walking (days/week) & 200 & 0.05 & 0.76 & 0.44 \\
\hline Age and walking (min/week) & 184 & 0.08 & 1.15 & 0.24 \\
\hline Age and sitting (hours/week) & 200 & -0.09 & -1.31 & 0.18 \\
\hline Age and sitting (min/week) & 200 & -0.09 & -1.32 & 0.18 \\
\hline
\end{tabular}




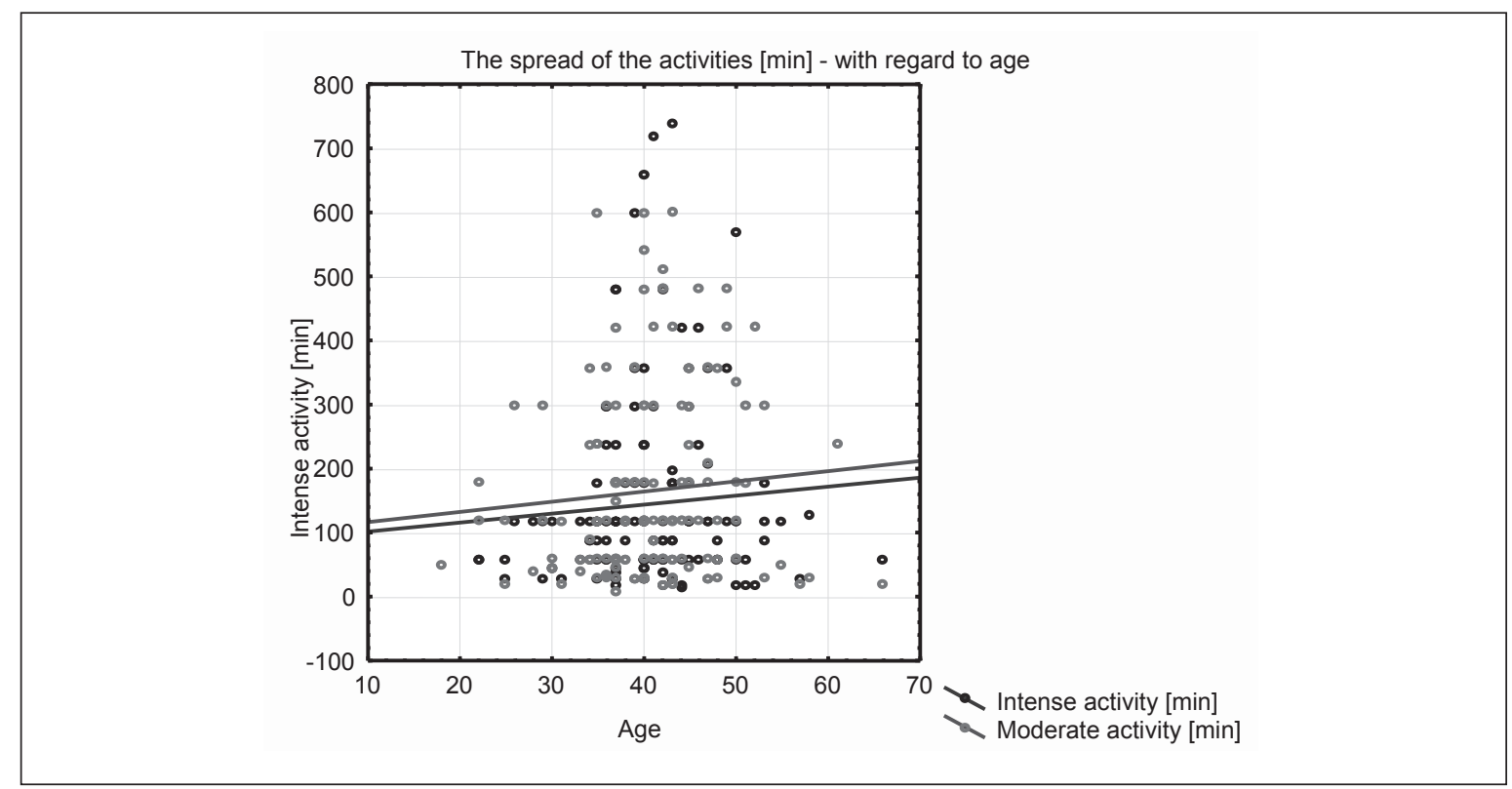

Fig. 7. The spread of intensive and moderate activity by age

The last of the determinants which could condition physical activity in the examined population to be considered was occupation. Occupation was divided into 8 groups with common characteristics, i.e. educational profile, job characteristics, professional level; unemployed persons were also included (Tab. 5, Fig. 10).

There is no statistically significant difference between occupation and the degree of activity intensity considered in days/week. For intense activ-

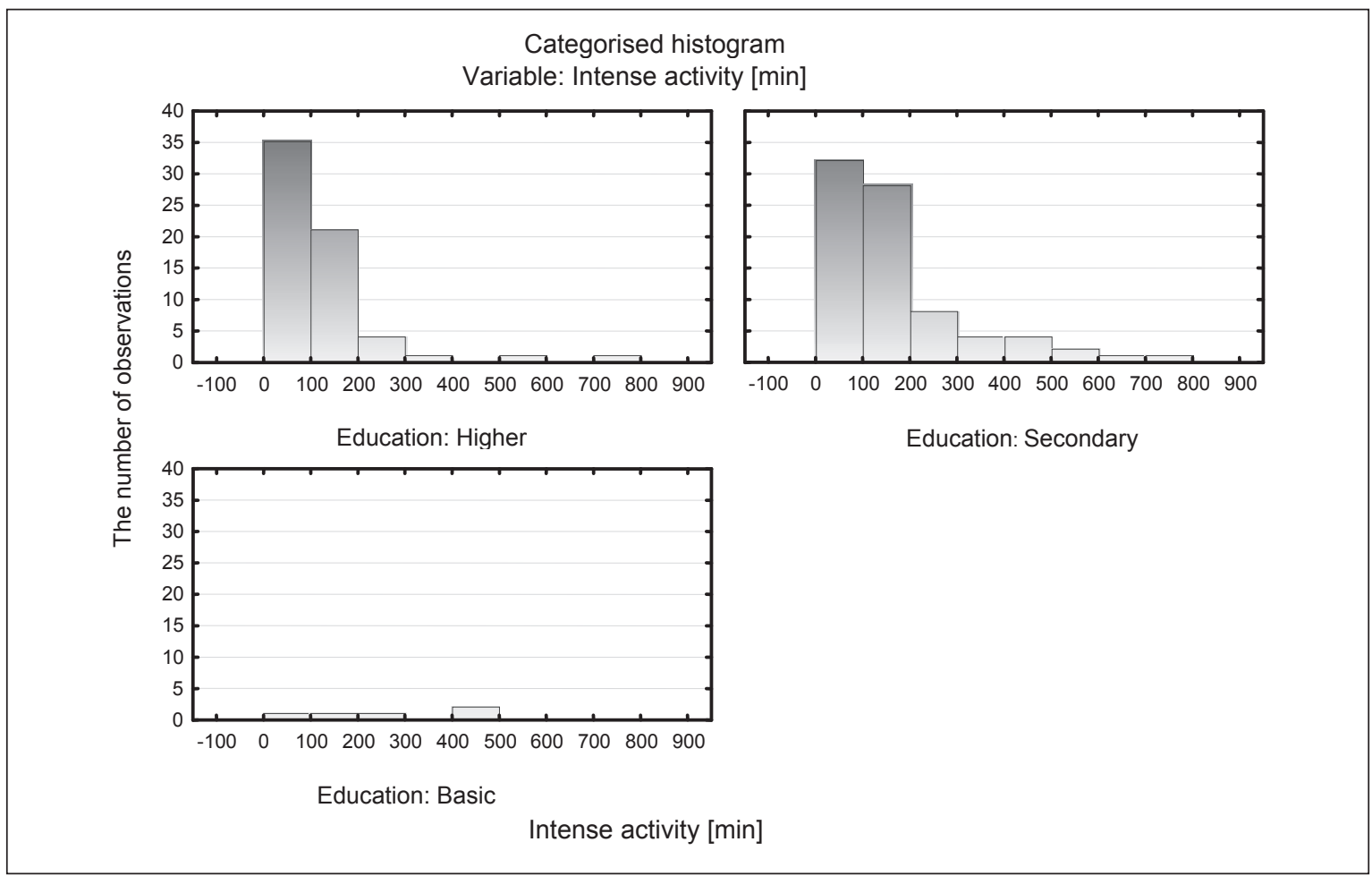

Fig. 8. Intensive physical activity in minutes per week and education level 


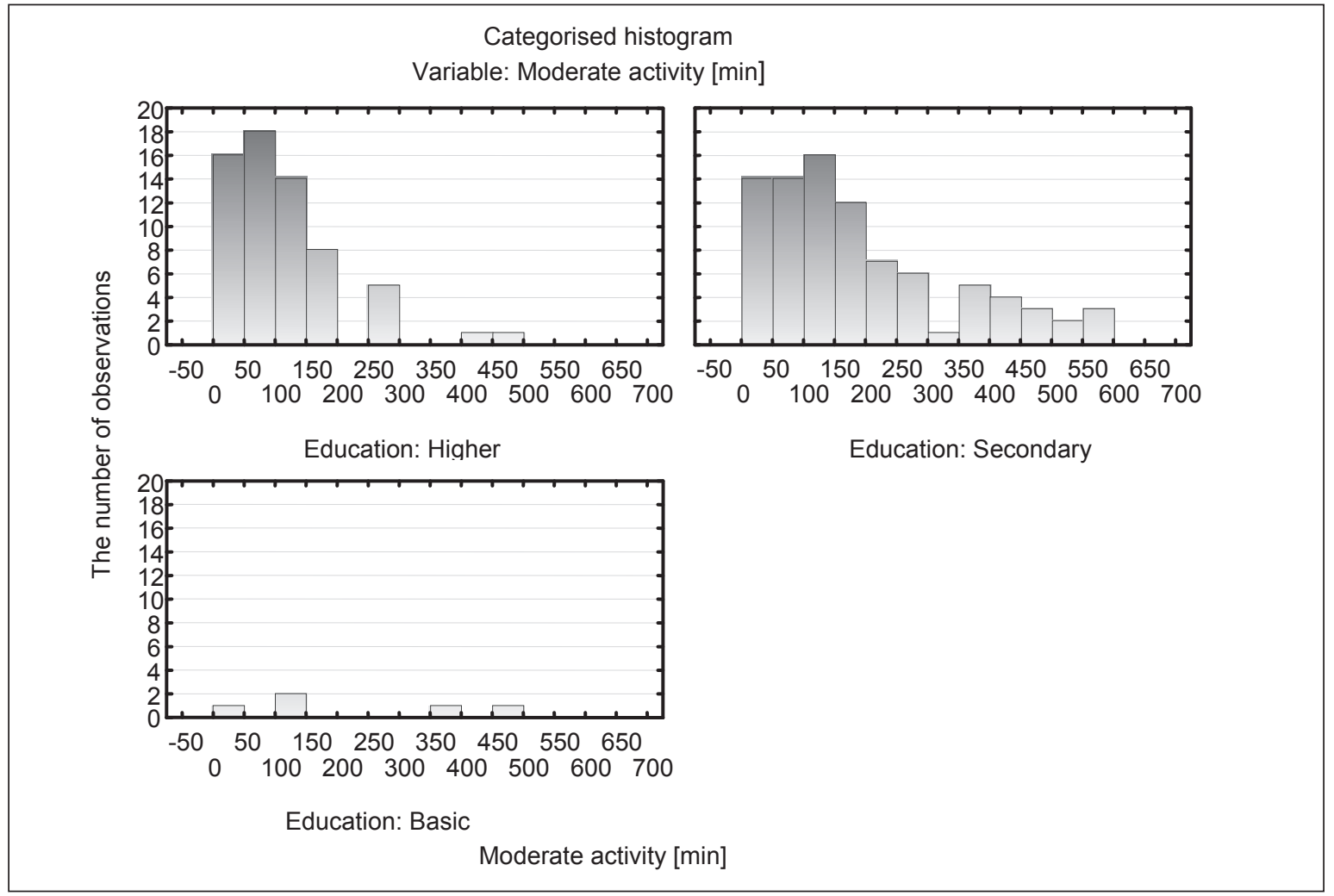

Fig. 9. Moderate physical activity in minutes per week and education level

ity it amounts to $p=0.4910$, and for moderate $p=$ 0.4248 . However, when considering moderate activity in minutes/week, there exists no significant difference $(p=0.0500)$ in relation to the characteristics of the profession, but we are close to the relevant range here, and we could expect a substantial difference between the professional group 2 and 4,2 and 8 and between 3 and 4 , as well as 3 and 8 .It means that there could be a statistically significant difference between humanists and those working in the commercial sector, humanists, and those unemployed. Such a difference could also be demonstrated between economists and rep-

Table 5. Professions/industries in the study population

\begin{tabular}{ccccc}
\hline & \multicolumn{4}{c}{ Table of cardinality: professions } \\
\cline { 2 - 4 } Profession/trade & Number & Cumulative group & Percentage & $\begin{array}{c}\text { Cumulative } \\
\text { percentage }\end{array}$ \\
\cline { 2 - 5 } & 22 & 22 & 9.78 & 9.77 \\
2. & 16 & 38 & 7.11 & 16.88 \\
3. & 35 & 73 & 15.56 & 32.44 \\
4. & 27 & 100 & 12.00 & 44.44 \\
5. & 32 & 132 & 14.22 & 58.66 \\
6. & 11 & 143 & 4.89 & 63.55 \\
7. & 74 & 217 & 32.89 & 96.44 \\
8. & 8 & 225 & 3.56 & 100.00 \\
\hline
\end{tabular}

KEY:

1. Medical

2. Pedagogical/Humanities

3. Economical

4. Trade/Sale
5. Building industry/Nocational

6. Technical/ Engineering

7. Different professions/Industries

8. Unemployed persons 


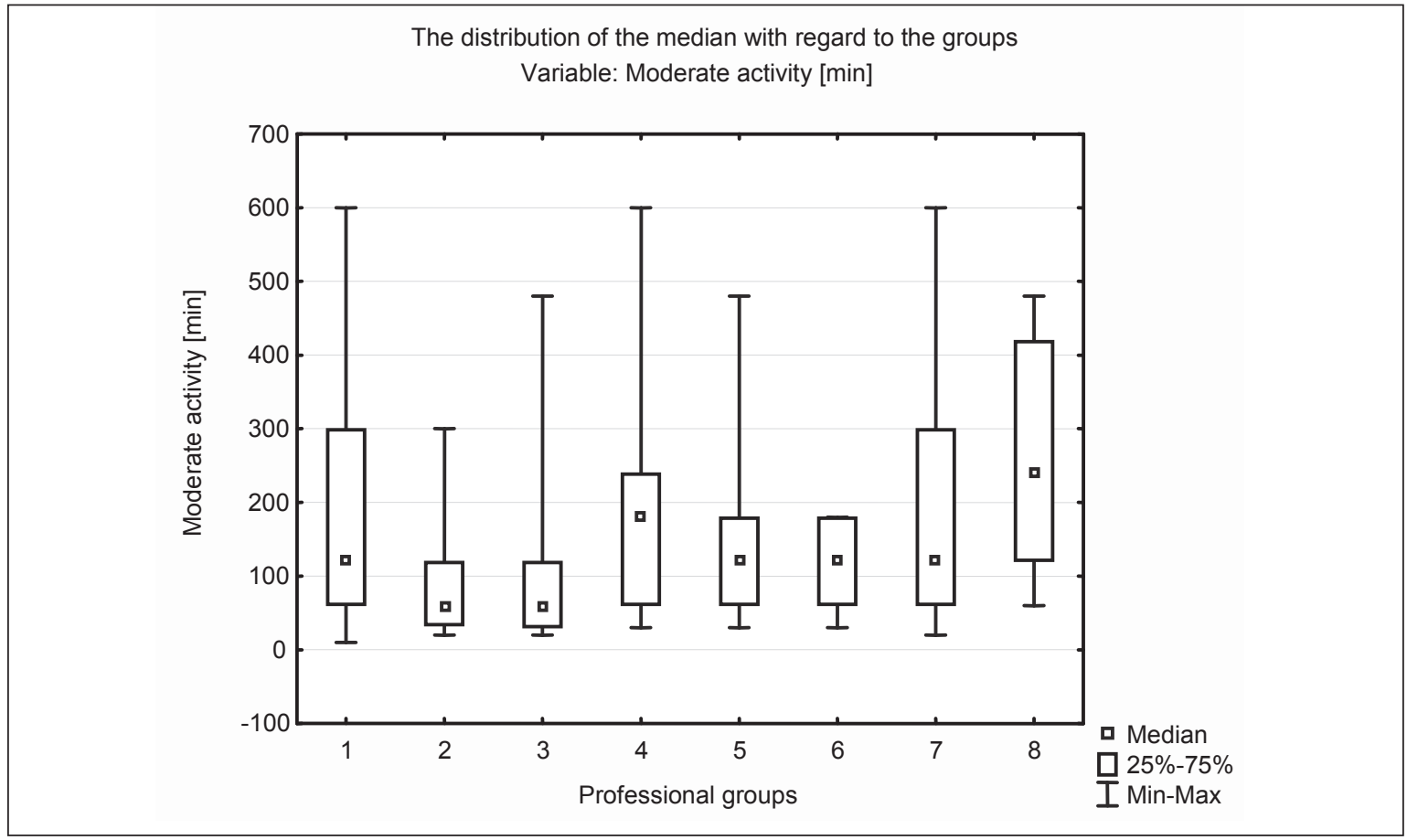

Fig. 10. The distribution of median in moderate physical activity in minutes per week and the individual professional groups

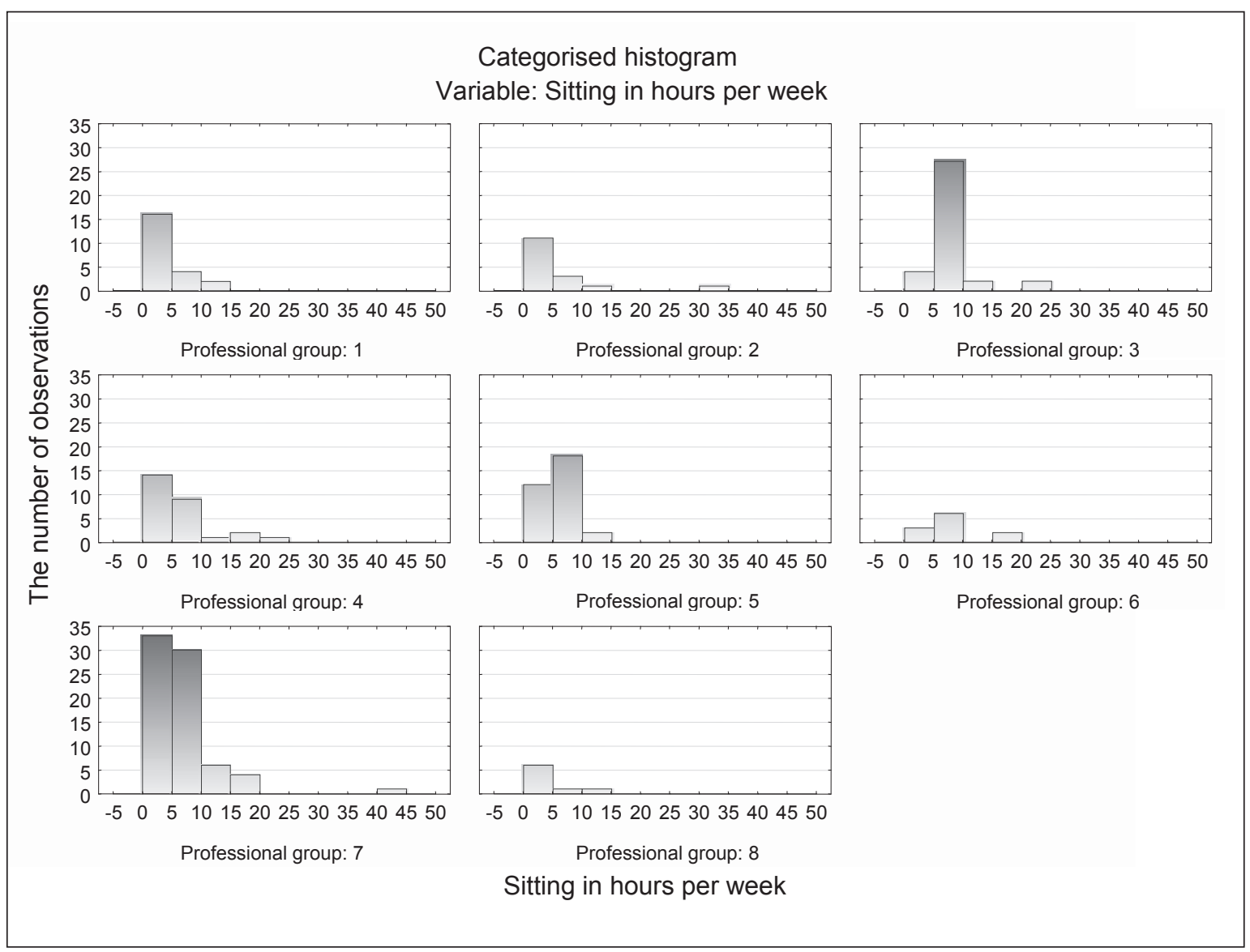

Fig. 11. Sitting in hours per week and the individual professional groups 


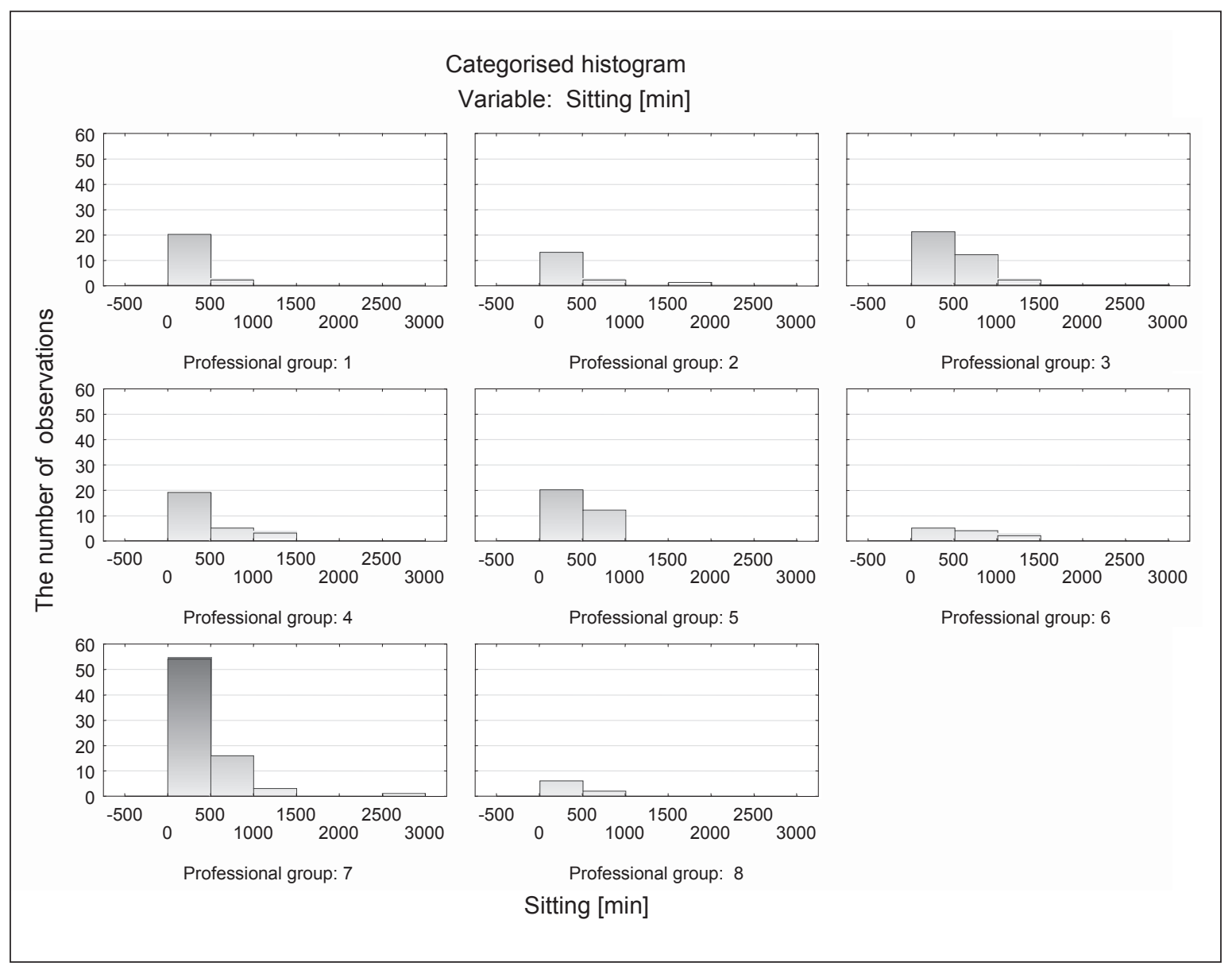

Fig. 12. Sitting in minutes per week and the individual professional groups

resentatives of the trade, as well as traders and those unemployed.

As in the case of intensive and moderate activity, there is no statistically significant difference, as far as walking/strolling in relation to one's profession is considered ( $p=0.7731)$, in days per week. Statistically significant difference exists between the subsidiary that is sitting, and the type of occupation, both in hours/week and minutes/week $(p=0.0015)$ (Fig. 11 and 12).

For example, a group of people employed in healthcare was compared with economists $(p=0.00019)$, and a group of people educated in arts with people educated in construction industry or with vocational education ( $p$ $=0.0275$ ). The relationship between economists and people unemployed is also interesting $(p=0.0240)$, but it is worth noting that in this case the differences may be caused by the non-uniform group sizes, which are nonetheless similar in the majority of the scheduled groups. The results may be reliable because the specifics of the various professions and the associated physical activity could be also confirmed in a study on a larger population.

\section{Discussion}

The recommendations on physical activity for maintaining or improving the health of people aged 18-65 presented in 2007 by ACSM and AHA suggest [8, 9, 10, 11, 12]:

- 30 minutes of moderate (aerobic) physical activity practiced 5 days a week, or 20 minutes of vigorous physical activity three days a week;

- combining moderate and intensive effort, because of the results being compatible with each other;

- moderate physical activity, such as brisk walking, which can be achieved by 30 minutes' effort divided into several 10-minute episodes;

- intense physical activity, defined as activity that causes a sharp increase in respiratory rate and heart rate, like jogging;

- moderate and intense physical activity, which should complement the low-intensity efforts such as shopping;

- performing exercises maintaining or increasing muscle mass at least twice a week. 
Further benefits, such as improved performance and efficiency, reduced risk of non-infective diseases and maintaining constant body mass can be achieved by going beyond the minimum recommendations on physical activity.

According to Czaja [13], recommendations for individuals aged 50-64 and over 65, and those suffering from chronic diseases, or for those who are under constant medical care involve:

- moderate activity depending on individual health and endurance;

- undertaking activities that will maintain or increase mobility and coordination;

- undertaking activities integrated with therapeutic recommendations.

It is estimated that about $30 \%$ of the adult population of Europe, including Poland, is characterized by low level of physical activity $[14,15]$. Our findings help establish the argument that the level of physical activity undertaken by adults $(\mathrm{N}=225)$ is varied and mostly inadequate as far as recommendations are concerned.

Dziubak and Motyka [16] got similar results, which support the fact that a significant part of the study group $(N=170)$, spend their free time passively (reading, watching TV, sitting in front of the computer, taking a nap, etc.), devoting to these activities the following number of hours per week: $1-5$ hours $-37.1 \%$ of the respondents, $6-10$ hours $-17.6 \%$, and $11-15$ hours $20 \%$ of respondents. The significant difference between the above-mentioned data and the results that the authors of this study found stems from the relatively short time spent sitting $-70.2 \%$ of the study group sit about 8 hours a week and $24.4 \%$ sit 8-16 hours a week, which is not a bad result; this result would also deny the thesis that the study group lead sedentary lifestyle. It is worth noting that in our study, sitting was considered a part of everyday human activity, and not as a way of spending free time evaluated in the long term (e.g. consumption of meals as a daily activity as opposed to watching TV as a way of spending free time).

In the general population, the frequency of optimally intensive physical activity is low. Only $31 \%$ of adults and $35 \%$ of adolescents meet the indications of daily energy expenditure during moderately intensive physical activity [17]. In our study, $68 \%$ of subjects declares engaging in intensive physical activity, but the duration of this type of effort is highly diversified.

Studies show that as many as $60-70 \%$ of the adult population in Poland lead a sedentary lifestyle. The majority of adult Poles spend their free time passively or performs actions that do not require physical effort, such as reading, watching TV or listening to the radio $[18,19]$. Our study shows that of all types of physical activity (intensive, moderate, walking/strolling) the largest group among the subjects $(70.2 \%)$ prefer sitting.

Woynarowska [4] writes that only every third Pole engages in moderately intensive effort, an average of 8 hours a week; intensive effort is undertaken by only $5 \%$ of people, with four times more men than women. An average Pole spends 18 hours a week on sedentary activities in their free time, or on doing things that require little physical effort. Similar trends were confirmed by the results of this study, in the light of which the subjects declared engaging in moderate activity 3 days a week for more than 2.5 hours (161.25 min), whereas $16 \%$ of subjects engaged in intensive activity for an average of two days a week for 2.5 hours. Activities not requiring much effort, such as sitting, were declared by all subjects, to be engaged in 7 days a week. Average duration of this activity was between 3-16 hours and gave approximately 9.5 hours a week.

The level of physical activity of the subjects depends largely on their age, education level, and financial situation. The younger the age, higher the level of education, better evaluation of the material situation, the higher the percentage of respondents practicing sports. Among the subjects aged 18-44 years with at least secondary education, who are satisfied with the material conditions of their households, the percentage of those practicing sports is higher than average [20]. The results obtained by the researchers from CBOS (Centre for Public Opinion Examination) partially overlap with the results obtained by the authors of this publication. This state of affairs may indicate predominance of passive forms of spending free time and be related to the type of work performed. The average physical activity of women during a week was 4 hours, with 6.5 hours for men, giving an average of slightly more than 5 hours a week. Such activity duration quantitatively meets the norm of recommended moderate activity, but various intensity of effort undertaken by the subjects should be taken into consideration.

In research conducted by Puciato et al., the chance of subjects fulfilling health-related physical activity recommendations decreased with increasing level of education. Among the examined inhabitants of Katowice, men significantly more often than women fulfilled healthpromoting physical activity recommendations [21], however, this fact is also recorded in other publications $[22,23]$. Identical results were obtained in our study, in which the physical activity undertaken by people with higher education was lower, and even inversely proportional to the level of education. It can also be observed that throughout the week, men more often than women engage in frequent and intensive physical exercise.

In reference to Woynarowska [4] and teams of experts from England, Canada and the USA [10, 12, 24, 25 ] the recommended level of physical activity equals 60 
or more minutes of daily, diverse activity of at least moderate intensity. Taken into account are the P.E. lessons, other organized physical activities, sport and walking (cycling) to and from school, work around the household, work in the garden and so on. Exercises to increase endurance, suppleness and strength of various muscle groups are especially recommended.

Due to the existence of a dose-response relationship between physical activity and health, adults who want to improve their physical fitness, as well as reduce the risk of chronic diseases and disabilities, and prevent weight gain, should undertake the minimum amount of physical activity recommended [3]. To be more specific, one should satisfy this criterion regardless of age, gender, education and socioeconomic status, to at least enjoy good health, and multiply one's own health potential through exercise, which is not only an element of physiology, but also of prevention.

In an adult group, physical exercises to improve endurance, muscle strength, balance, coordination and suppleness should be applied. The greatest benefits of physical exercise is observed in people who perform moderate exercises focusing on endurance and expand them with resistance exercises [3].

Many recent publications suggest that sedentary lifestyle is one of the most important public health problems in industrialized countries. In many countries, the percentage of people with too little physical activity goes as far as $60-70 \%$ of the population of adults and at least $30-50 \%$ of children and adolescents. The effects this mass hypokinesia has on health, society and economy are quite dramatic [26]. For adults, it is sometimes difficult to change behaviors resulting from beliefs and habits, therefore, at least as far as education and health promotion activities are concerned, the benefits and/or risks of engaging in or lack of physical activity should be pronounced. It is why the importance of early health education is so often emphasized, so that a young, developing human does not manage to fix unhealthy behavior, including the tendency to "motor minimalism", which can have negative effects on their health in their adult life, as well as in old age.

\section{Conclusions}

1. Gender determines the level of physical activity. Most women engage in intensive physical effort more seldom and for shorter time than men (on weekly basis). There is a statistically significant difference between intense and moderate activity depending on gender.

2. The study shows that age is not a factor in determining the level of physical activity of the examined group.

3. The level of physical activity does not increase with the level of education. People with secondary education engage in longer and more frequent physical activity (both intense and moderate) more often than those with higher and primary education. The higher the level of education, the smaller the scope and nature of the physical activity engaged in.

4. There is no statistically significant difference between profession and intense physical activity, moderate physical activity and walking.

5. There is a significant difference between profession and the time spent on sitting.

\section{Reference literature}

[1] Dąbrowska A, Kalecińska J: Społeczno-wychowawcze uwarunkowania rekreacji ruchowej; w Dąbrowski A. Zarys teorii rekreacji ruchowej. Warszawa, Zakład Wydawniczy Druk Tur, 2006: 49 (Sociological and educational conditions of physical recreation).

[2] Wit B: Fizjologiczny aspekt uczestnictwa w rekreacji ruchowej; w Dąbrowski A. Zarys teorii rekreacji ruchowej. Warszawa, Zakład Wydawniczy Druk Tur, 2006: 194 (Physiological aspect of taking part in physical recreation).

[3] Jegier A: Aktywność fizyczna dorosłych osób - korzyści zdrowotne i obowiązujące zalecenia; w Jegier A., Nazar K., Dziak A. Medycyna sportowa. Warszawa, PZWL, 2013: 242-249. (Physical activity of adults).

[4] Woynarowska B: Edukacja zdrowotna. Warszawa, PWN, 2013: 298-320. (Health education).

[5] Narodowy Program Zdrowia na lata 1996-2005, 2007-2015. (www.mz.gov.pl) (National Health Programme for years 19962005 and 2007-2015).

[6] Jegier A:Aktywność ruchowa w promocji zdrowia oraz zapobieganiu i leczeniu chorób przewlekłych; w Jegier A, NazarK, DziakA (red.): Medycyna sportowa. Warszawa, Polskie Towarzystwo Medycyny Sportowej, 2005: 403. (Physical activity in promoting health and preventing chronic diseases).

[7] Lisowska J: Rekreacja ruchowa osób dorostych; w Dąbrowski A. Zarys teorii rekreacji ruchowej. Warszawa, Zakład Wydawniczy Druk Tur, 2006: 89 (Recreation of adults).

[8] Blair SN, LaMonte MJ, Nichman MZ: The evolution of physical activity recommendations: how much is enough? Am J Clin Nutr 2004, 79: 913-920.

[9] Brien SE, Katzmarzyk PE: Physical activity and the metabolic syndrome in Canada. Appl Physiol Nutr Metab 2006, 31: 40-47. 
[10] Haskell WL, Lee I-M, Pate RR, Powell KE, Blair SN, Franklin BA, et al.: Physical Activity and Public Health: Updated Recommendation for Adults from the American College of Sports Medicine and the American Heart Association. Circulation 2007, 116: 1081-1093.

[11] Position of the American Dietetic Association and the Dietitians of Canada: Nutrition and Women's Health. J Am Diet Assoc 2004, 104(6): 984-1001.

[12] Perk J, De Backer G, Gohlke H, Graham I, Reiner Z, Verschuren WMM, et al., European Guidelines on Cardiovascular Disease and Prevention in Clinical Practice (version 2012). The Fifth Join Task Force of the European Society of Cardiology and Other Societes on Cardiovascular Disease Prevention in Clinical Practice (constituted by representatives of nine societies and by invited experts). Eur Heart J 2012, 33:1635-1701.

[13] Czaja J: Bromatologiczna ocena czynników optymalizujących dietę osób aktywnych fizycznie - rozprawa doktorska. Gdańsk, GUM, 2010: 9. (Assesment of the factors optimizing diet for active people, from the point of view of nutritional science).

[14] Participation of Poles in sports and physical recreation. Warszawa, Główny Urząd Statystyczny, 2009.

[15] Sjöström M, Oja P, Hagströmer M, Smith B, Bauman A: Health-enchancing physical activity across European Union countries: The Eurobarometer study. J Publ Health 2006, 14(5): 291-300.

[16] Dziubak M, Motyka H: Analiza wybranych zachowań zdrowotnych kształtujących wskaźnik masy ciała osób dorosłych w aspekcie nadwagi i otyłości; w Żarow R (red.): Człowiek w zdrowiu i chorobie, promocja zdrowia, leczenie i rehabilitacja. Tarnów, PWSZ, 2012: 231. (An analysis of selected healthy behaviors in the context of overweight and obesity).

[17] National Center for Health Statistics. Chartbook on Trends in the Health of Americans. Health, United States 2008, Hyattsville, MD: Public Health Service.

[18] Bronkowska M, Martynowicz H, Żmich K, Szuba A, Biernat J: Wybrane elementy stylu życia oraz wiedza żywieniowa otyłych osób z rozpoznanym nadciśnieniem tętniczym. Nadciśn Tętn 2009, 13(4): 266-274. (Selected elements of lifestyle of obese people with hypertension, and their knowledge on nutrition).

[19] Piechota G, Kalinowski P, Karwat I: Otyłość - epidemia o zasięgu światowym. Now Lek 2008, 77(2): 158-161. (Obesity a global epidemics).

[20] Omyła-Rudzka M: Aktywność fizyczna Polaków. Komunikat z badań nr 4887, BS/129/2013 (www.cbos.pl), [dostęp: 24.03.2014] (Physical activity of Polish people).

[21] Puciato D, Rozpara M, Mynarski W, Łoś A, Królikowska B: Aktywność fizyczna dorosłych mieszkańców Katowic a wybrane uwarunkowania zawodowe i społeczno-ekonomiczne. Med Pr 2013: 64(5): 649-657. (Acvtivity of adult citizens of Katowice).

[22] Kaleta D, Jegier A: Rekreacyjna aktywność ruchowa w losowej próbie mieszkańców Łodzi w wieku produkcyjnym - wyniki badania wstępnego. Med Pr 2003; 54(6):563-566 (Physical activity of citizens of Łódź).

[23] Cleland V, Ball K, Crawford D: Socioeconomic position and physical activity among women in Melbourne, Australia: Does the use of different socioeconomic indicators matter ? Soc Sci Med 2012; 74(10):1578-1583.

[24] ACSM's Guidelines for Exercise Testing and Prescription. Philadelphia, Wolters Kluwer/Lippincott Williams\&Wilkins, 2010.

[25] WHO Global Recommendations on Physical activity for Health 2010. Retrieved 17.04.2014 from http://whqlibdoc. who.int/ publications/2010/9789241599979_eng.pdf.

[26] Drygas W, Jegier A: Zalecenia dotyczące aktywności ruchowej w profilaktyce chorób układu krążenia, s.15, http://www. umed.edu.pl/geriatria/pdf/Zalecenia_dotyczace_aktywnosci_ruchowej_w_profilaktyce_chorob_ukladu_krazenia.pdf, [dostęp: 25.03.14]. (Recommendations on physical activity).

\author{
Word count: 5.874 \\ Tables: 5 \\ Figures: 12 \\ References: 26
}

\title{
Corresponding author:
}

\section{Dorota Lizak}

Health and Medical Sciences Faculty, Andrzej Frycz Modrzewski Krakow University,

1 Gustawa Herlinga-Grudzińskiego Street, 30-705 Krakow, Poland

E-mail: dlizak@afm.edu.pl, Tel.: 0048697812500 